doi: 10.17492/pragati.v2i2.8614

\title{
Livelihood, Employment and Skills for Young Women in Urban India
}

\author{
Vibhuti Patel *
}

\begin{abstract}
This paper seeks to examine and address the issue of the right to work of adolescent girls. Lack of implementation of laws, lack of awareness of rights enshrined in the laws coupled with a lack of access to justice for adolescent girls, brings to the fore the importance of pro-active policies for adolescent girls at work as a complementing strategy. The policies should be geared towards supporting adolescent girls for building skills such as life skills and vocational skills, and for having savings independent of their families, in order that they can become economically independent. Micro-credit facilities and facilities for on-site banking for girls and young women at their place of work are some strategies that can work towards this end. Laws related to eradication of child labour, bonded labour and protecting girls at the workplace ought to be implemented in a rigorous manner.
\end{abstract}

Keywords: Young women, Livelihood, Right to Work, Labour laws, Skill development.

\subsection{Introduction}

"Young men and women today build the foundations for the economies and societies of today and tomorrow. They bring energy, talent and creativity to economies and make important contributions as productive workers, entrepreneurs, consumers, agents of change and as members of civil society. There is no doubt that what young people strive for is the chance of a decent and productive job from which to build a better future. Take away that hope and you are left with a disillusioned youth trapped in a cycle of working poverty or in danger of detaching from the labour market altogether - thus representing a vast waste of economic potential". ${ }^{1}$ The stated quote provides the rationale for examining and addressing the challenges faced by youth at work.

*Professor and Head, Department of Economics, SNDT Women's University, Mumbai. 
The underlying patriarchal attitudes and practices, situated in the context of increasing capitalism and economic globalisation (which is largely exploitative), provide further reasons for examining, understanding and addressing adolescent girls and their right to work, as well as rights in work (conditions of work). This is partially what the present study seeks to do. Additionally, international standards, national laws, policies, programmes and strategies with regard to adolescent girls' work will also be discussed and critiqued. A considerable amount of work contributed by girls is unpaid labour that is not valued in monetary terms, and yet, such work is extremely important for the functioning of any economy. This study will, however, focus on the paid work of adolescent girls.

\subsection{Global Youth and Right to Work}

The 2010 ILO report on Global Employment Trends for Youth reflects today's global reality of young workers (between the ages of 15 and 24) at work. Based on recent labour market information available, the report explores and highlights the vulnerabilities of youth to unemployment and decent work deficits, showing where progress has or has not been made in absorbing the energy, talent and creativity of young people into the productive potential of the economy. The key findings of the report were:

- The youth labour force participation rate decreased globally from 54.7 to 50.8 per cent between 1998 and 2008. The main reason is the increase in number of young people participating in the education system.

- Young people have a higher likelihood than adults of being among the working poor. An estimated 152 million young workers were living in poor households in 2008.

- In developing economies many more young people than adults engage in family businesses (likely to be an informal enterprise) or farms. The chances for many young people in low-income countries of ever transiting to paid employment in the formal sector are slim.

- Most regions demonstrated encouraging gender trends with decreasing gaps in both male-to-female labour force participation rates.

- During 2007-9 when there was a global economic crisis, young women have more difficulty than young men in finding work, and have been hit harder by unemployment than young men.

- In developing countries, the global economic crisis contributes to 
"vulnerable employment" "3 and informal sector employment

When the last two findings are combined, there is a clear indication that worldwide, adolescent girls and young women are forced into informal sector employment and employment where their rights are not likely to be protected, out of desperation of wanting to find work.

\subsection{International Human Rights Standards related to Work}

Workers' struggles have been essential to the recognition of a range of economic, social and cultural rights, including the right to work. The International Labour Organization (ILO) existed and developed a broad range of labour-related standards, even prior to the United Nations or the drafting of the Universal Declaration of Human Rights. India has ratified a number of international conventions that focus directly or have provisions on women's rights at the workplace. Through ratification, such international standards become applicable to India. Such Conventions include:

- ILO Underground Work (Women) Convention, 1935 (No. 45) (ratified on 25/03/1938) ILO Underground Work (Women) Convention, 1935 (No. 45) (ratified on 25/03/1938)

- ILO Night Work (Women) (Revised) Convention, 1948; and Protocol, 1990 (No. 89) (ratified on 27/02/1950)

- ILO Equal Remuneration Convention, 1951 (No. 100) (ratified on 25/09/1958)

- ILO Discrimination (Employment and Occupation) Convention 1958 (No. 111) (ratified on 03/06/1960)

- ILO Discrimination (Employment and Occupation) Convention, 1958(No. 111) (ratified on 03/06/1960)

- ILO Employment Policy Convention, 1964 (No. 122) (ratified on 17/11/1998), ILO Benzene Convention, 1971 (No. 136) (ratified on 11/06/1991)

- ILO Rural Workers' Organisations Convention, 1975 (No. 141) (ratified on 18/08/1977)

- UN Convention on the Elimination of All Forms of Discrimination against Women, 1979 (ratified on 09/07/93)

- UN Covenant on Economic, Social and Cultural Rights, 1966 (ICESCR) (acceded to 10/04/1979)

- UN Covenant on Civil and Political Rights, 1966 (ICCPR) (acceded to 10/04/1979) UN Convention on the Political Rights of Women, 1953 (ratified on $01 / 11 / 1961)$ 
22 | PRAGATI: Journal of Indian Economy, Volume 2, Issue 2

\subsection{Standards set by Human Rights treaties}

Article 23 of the Universal Declaration of Human Rights (UDHR) guarantees everyone "the right to work, to free employment, to just and favourable conditions of work and to protection against unemployment." The ICESCR contains specific provisions on the right to work. Article 6 of the ICESCR states that the right to work includes "the right of everyone to the opportunity to gain his living by work." Work as a human rights standard involves earning an adequate standard of living. Further, Article 6(2) states that "the full realization of this right shall include technical and vocational guidance and training programmes." Article 1(2) of ILO Convention No. 122 calls upon each member to ensure that "there is work for all who are available for and seeking work." The right to work thus ensures that nobody is excluded from the economic activities of their family / community / state. The human right to work includes:

- distribution of work in such a way that allows participation of everyone (the right to participate in economic activities),

○ such work should allow persons to earn their living,

- access to resources, education and training,

- the benefits from the economic activity should be enough to have an adequate standard of living,

- right to freely chosen and accepted work, conditional upon the possibility of earning a living through that work.

\subsection{Directives of the European Union}

The European Union's directives to its member states on the issue of protecting young people at work are an example of standard-setting on this issue ${ }^{4}$. While such directives are applicable only to member countries of the European Union, these are discussed below to illustrate potential ways in which the Indian government can safeguard the rights of adolescent girls at work. A summary of the directive is as follows:

- Objective: To adopt minimum requirements aimed in particular at improving working conditions, guaranteeing workers better health and safety protection.

- Application: The Directive applies to all young people under the age of 18 who have an employment contract or an employment relationship defined by the law in force in a Member State and/or subject to the law in force in a Member State.

- Categories / Definitions: The categories include (i) young people under the age of 18, (ii) children: young people under the age of 15 or who are still in full-time compulsory education in accordance with national legislation, 
and (iii) adolescents: young people between the ages of 15 and 18 who are no longer in full- time compulsory education in accordance with national legislation.

- Provides for: Member States to take the necessary measures to prohibit the employment of children and shall ensure that the employment of adolescents is strictly controlled and protected under the conditions provided for in the Directive.

- Provides exceptions to blanket ban on employment of children.

- Lists the employer's general obligations: Such as protection of the health and safety of young people, assessment of the risks to young people associated with their work, assessment and monitoring of the health of young people, information about young people and children's legal representatives on the possible risks to their health and safety.

- Lists types of employment that are prohibited for young people: These include the following: (i) work which is objectively beyond their physical or psychological capacity; (ii) work involving harmful exposure to agents which are toxic, carcinogenic, cause heritable genetic damage, or harm to the unborn child or which in any other way chronically affect human health; and (iii) work involving harmful exposure to radiation; (iv) work involving the risk of accidents which it may be assumed cannot be recognized or avoided by young persons owing to their insufficient attention to safety or lack of experience or training; or (v) work in which there is a risk to health from extreme cold or heat, or from noise or vibration.

- Provisions regulating working conditions: The directive contains provisions relating to other working conditions such as: (i) maximum working time of eight hours a day, 40 hours a week; (ii) prohibits night work - between $10 \mathrm{pm}$ and 6 am or $11 \mathrm{pm}$ and $7 \mathrm{am}$; and (iii) specific provisions on rest periods and annual leave.

- Member states' responsibilities: (i) to implement the directive in the form of a legislation in their respective countries; (ii) to define necessary measures applicable in the event of infringement of the provisions of this Directive; and (iii) to ensure that such measures must be effective and proportionate to the offence.

In the Indian context, since adolescent girls at work also include girls who are pregnant, have recently given birth or are breast feeding, the European Union directive on this issue are relevant to examine state responsibility in other jurisdictions. A summary of the European Council directive on protection of pregnant women, women who have recently given birth and 
women who are breastfeeding is as follows: ${ }^{5}$

- Objective: To take minimum measures to protect the health and safety of pregnant workers, women workers who have recently given birth and women who are breastfeeding, considering them to be a specific risk group.

$\circ$ Guidelines on aspects that are dangerous for health and safety of the concerned workers: In consultation with the Member States and assisted by the Advisory Committee on Safety, Hygiene and Health Protection at Work, the directive calls upon the European Commission to draw up guidelines on the assessment of the chemical, physical and biological agents and industrial processes considered dangerous for the health and safety of the relevant workers, to include physical movements and postures, mental and physical fatigue and other types of physical and mental stress.

- For all activities liable to involve a risk, the employer or the health and safety service must determine the nature, degree and duration of exposure in order to evaluate the risks and decide what measures should be taken. Workers need to be notified of the results and of measures involving health and safety at work.

- Employers' duties: Exposure of the workers in question to the above risks to be avoided by provisionally adjusting their working conditions or their working hours. Where such adjustment is not technically and/or objectively feasible, or cannot reasonably be required on duly substantiated grounds, the employer shall take the necessary measures to move the worker concerned to another job. Where transfer to another activity is not feasible, the workers in question must be granted leave for the whole of the period considered necessary to protect their safety and health.

- Maternity leave to be given for an uninterrupted period of at least 14 weeks before and/or after delivery.

- Other conditions of work: These include (i) Pregnant workers have the right to take leave from work without loss of pay to enable them to attend ante-natal examinations if such examinations take place during working hours; (ii) Prohibition of dismissal of women for reasons related to their condition, protective measures for unlawful dismissal; and (iii) an adequate allowance for health insurance.

- State responsibilities: These include the following: (i) To implement the directive in the form of a legislation in the respective countries; (ii) To introduce into their national legal systems such measures as are necessary to enable workers who consider themselves wronged by failure to comply with the obligations arising from this Directive to pursue their 
claims by judicial process or by recourse to other competent authorities; (iii) To report to the Commission every five years on the practical implementation of the Directive, indicating the points of view of the two sides of industry.

\subsection{Constitution and Labour Laws in India}

The Constitution sets out a number of fundamental rights, generally enforceable in the courts. These include equality before the law and equal protection under the law (Article 14), and prohibition on discrimination by the State on a number of grounds, including sex (Article 15), in spheres including public employment (Article 16). In addition, the State can make affirmative action in favour of women, including through reservation and special laws (Article 15(3)). The State is duty-bound to protect the life and personal liberty of all, including women (Article 21). The Constitution also directs the state to provide equal pay for equal work (Article 39(d)), and make provisions for ensuring just and humane conditions of work and maternity relief (Article 42). The Constitution further states, in the fundamental rights chapter, that no child below the age of 14 years shall be employed to work in any factory / mine / other hazardous employment (Article 24). The right to primary education has been included as a fundamental right. ${ }^{6}$ The Constitution further directs the state to ensure that children are given opportunities and facilities to develop in a healthy manner and in conditions of freedom and dignity and that childhood and youth is protected against moral and material abandonment (Article 39(f)).

Labour laws aim at protecting and promoting workers' rights at the work place. Provisions of labour laws have focussed on prohibiting / regulating child labour, particularly in hazardous work, and on improving the safety, health and welfare of women and girls in factories and other places of work, minimum wages, equal pay for equal work, maternity benefits, child care facilities, provisions for adequate rest and leisure, prevention of discrimination and sexual harassment at the work place. Many labour laws are an elaboration of principles and directives stated in the Constitution. For example, the equal pay for equal work clause led to the enactment of The Equal Remuneration Act, 1976. The emphasis on just and humane conditions of work led to provisions in Factories Act and other labour laws, prescribing for separate toilets for women and girls, and provision of crèches, and the prohibition of employment of women in dangerous or arduous jobs and night employment. The direction to the State to provide maternity relief's resulted in the enactment of The Maternity Benefits Act, 1961. 
Under the Constitution of India, labour is a subject in the 'Concurrent List'. This means that both the central and state governments are competent to enact legislations pertaining to the same. Labour laws that protect women at the work place (and are implicitly applicable to adolescent girls) include:

- The Equal Remuneration Act, 1976 - P rovides for equal remuneration to men and women workers for same work or similar work, and prohibits discrimination is permissible in recruitment and service conditions except where employment of women is prohibited or restricted by the law.

- Maternity Benefit Act, 1961 - Provides for maternity leave and benefit in order to protect the dignity of motherhood and gender justice.

- The Factories Act, 1948 - The Act has many provisions protecting women at the workplace, including issues pertaining to occupational safety, provision of sanitation and crèche facilities. ${ }^{7}$

- The Mines Act, 1952 - It prohibits the employment of women underground, and provides for restricted timings of work for women employed above the ground.

- Payment of Wages Act 1936 \& the Minimum Wages Act 1948 - Provides for regular and timely payment of wages; industry wage boards are mandated to fix the wage structure for each industry. No payment below the minimum wages prescribed is allowed.

- Employees Compensation Act 1923 - Provides for compensation to workers for industrial accidents and occupational diseases leading to disability or death.

- The Industrial Disputes Act 1947-The law covers layoffs, compensation for retrenchments, labour-management disputes and unfair labour practices; labour courts and industrial tribunals deal with disputes covered by this law.

- The Payment of Gratuity Act 1972 - Requires employers to pay a gratuity to workers earning less than a certain limit upon their termination of service.

- The Employees Provident Fund Act - applies to most establishments that employ at least 20 workers. Employers and employees contribute 10-12\% of the basic wage and dearness allowance of the employee. From the employer's contribution, a certain amount is diverted to the Pension Fund. Four main types of pension are offered: a monthly pension upon superannuation or disability; a monthly widows' pension for death while in service; a monthly children's pension; and a monthly orphan's pension.

- The Apprentices Act 1961 - regulates the programme of training apprentices in the industry so as to conform to the syllabi, period of training etc. as laid down by the Central Apprenticeship Council. 
- Child Labour (Prohibition and Regulation) Act 1986 - prohibits child labour in hazardous occupations and regulates conditions of work in the nonhazardous ones.

- Other laws pertaining to rights of workers, which benefit women and girls These include Bonded Labour System (Abolition) Act 1976, Plantation Labour Act 1951, Industrial Employment (Standing Orders) Act 1946, Trade Union Act 1926, Payment of Bonus Act 1955, Personal Injuries (Compensation Insurance) Act 1963, Employees State Insurance Act 1948, Interstate Migrant Workmen (Regulation of Employment) Conditions of Service Act, 1979 and The Contract Labour (Prohibition and Regulation) Act 1970. ${ }^{8}$

\subsection{Child Labour}

Child Labour may be defined to include children prematurely leading adult lives, working with or without wages, under conditions damaging to their physical, social, emotional and spiritual development, denying them their basic rights to education, health and development. This includes children working in any sector, occupation or process, including the formal and non-formal, organised and unorganised, within or outside the family. The organisation Free the Children defines child labour as a work done by children below the age of 14 "... which restricts or damages their physical, emotional, intellectual, social or spiritual growth as children." UNICEF describes child labour as "one of the clearest and worst manifestations of how poverty has a child's face". 9

It is important to remember that protective laws are able to regulate the conditions of work in the unorganised and informal sector to a lesser extent than in the organised sector. The government ought to address the causes of child labour, instead of its manifestations. The causes of child labour include poverty, lack of education and exposure, poor access to education, suppression of workers' rights, and partial prohibition of child labour and inadequate enforcement of child labour laws. Employment of girl children is intricately linked to class and caste hierarchy, social attitude towards education of girls as well as gender discrimination. Education of girls is considered a waste while education of boys is considered an investment. Rural poor illiterate parents abandon girl children, who end up with a life in a brothel or street prostitution; some of them escape to streets and beg, collect scrap and finally end up as prostitutes. Sexual abuse of girl children and adolescent girls employed in domestic work is rampant. 
Adolescent girls are also considered one of the most vulnerable groups for exploitation at work, due to the process of socialisation. They are conditioned to be more docile, timid, compliant, loyal and responsible. They are seen to have less addictions or vices, and more hardworking and obedient than boys. Significant characteristics of the girl child labourer include invisible work which is not recognized as an economic activity and which is not under the purview of law; no identifiable employer; home-based work; long working hours; poor conditions that prevent them from attending school; no skill formation; low pay and low status; and physical abuse and sexual harassment. ${ }^{10}$ This places an onus on the law and policy makers and to formulate relevant laws and policies to address possible exploitation, and for their proper implementation.

\subsection{Policy framework}

The National Policy on Child Labour, August 1987 spelled out an action plan for tackling the problem of child labour. It envisaged a legislative action plan; focussed on and convergence of general development programmes for benefiting children wherever possible; and project-based action plan of action for launching of projects for the welfare of working children in areas of high concentration of child labour.

In pursuance of National Child Labour Policy, the National Child Labour Project (NCLP) Scheme was started in 1988 to rehabilitate child labour. The Scheme sought to adopt a sequential approach with focus on rehabilitation of children working in hazardous occupations and processes in the first instance. Under the Scheme, after a survey of child labour engaged in hazardous occupations and processes has been conducted, children are to be withdrawn from these occupations and processes and then put into special schools in order to enable them to be mainstreamed into formal schooling system. The Scheme envisages running of special schools for child labour withdrawn from work. In the special schools, these children are provided formal/nonformal education along with vocational training, a stipend of Rs.100 per month, supplementary nutrition and regular health check-ups so as to prepare them to join regular mainstream schools. Under the Scheme, funds are given to the District Collectors for running special schools for child labour. Most of these schools are run by the NGOs in the district. According to the Ministry of Labour and Employment, Government of India, the coverage of the NCLP Scheme has increased from 12 districts in 1988 to 100 districts in the Ninth Plan (1997-2002) to 250 districts during the Tenth Plan (20032007). 
In 2001, an evaluation of the Scheme was carried out by independent agencies in coordination with V.V.Giri National Labour Institute. Based on the recommendations of the evaluation and experience of implementing the scheme since 1988, the strategy for implementing the scheme during the Tenth Plan was devised. The Tenth Plan aimed at greater convergence with the other developmental schemes and bringing qualitative changes in the Scheme. Salient points of the strategy as envisaged by the Tenth Plan include:

- Focused and reinforced action to eliminate child labour in the hazardous occupations by the end of the Plan period;

- Expansion of National Child Labour Projects to additional 150 districts;

- Linking the child labour elimination efforts with the Scheme of Sarva Shiksha Abhiyan of Ministry of Human Resource Development to ensure that children in the age group of 5-8 years get directly admitted to regular schools and that the older working children are mainstreamed to the formal education system through special schools functioning under the NCLP Scheme; and

- Convergence with other Schemes of the Departments of Education, Rural Development, Health and Women and Child Development for the ultimate attainment of the objective in a time bound manner.

- The strategy outlined for the 11th Five Year plan (2007-12) includes expanding the NCLP scheme to ensure universal enrolment of children in the 6-14 age groups to cover those in the hard-to- reach segment. It also includes substantial improvements in the quality and standard of education and teacher training. Another Government initiative under the Eleventh plan is to amend all laws to recognise everyone under the age of 18 as children and to take appropriate measures to protect their rights accordingly ${ }^{11}$.

\subsection{Protective laws}

The enactment of the Factories Act and the Child Labour (Prohibition and Regulation) Act 1986 further complement the constitutional provisions on child labour. The Factories Act prohibits employment of children below the age of 14 years in factories, and regulates the working conditions of children between the ages of 15 and 18 years. The latter law prohibits child labour in hazardous occupations and regulates the conditions of work in non-hazardous ones. Employment of children has been prohibited in at least 13 occupations and 51 processes in the country, with more and more hazardous occupations and processes added to the list from time to time. In 2006, the Central Government amended the Child Labour (Prohibition and 
Regulation) Act, 1986 prohibiting employment of children below 14 years of age even in non-hazardous industry such as restaurants, motels and in domestic work ${ }^{12}$. To further strengthen the process of elimination of child labour, the Ministry of Labour has signed a Memorandum of Understanding with the International Labour Organization on the same.

Through a 2008 notification, the government sought to further amend and add to the list of occupations and processes in which child labour is prohibited. These include the food processing and beverage industries, mechanised fishing, timber handling and loading, and warehousing ${ }^{13}$. In June 2012, the chairperson of National Commission for Protection of Child Rights, Ms. Shanta Sinha, has reportedly said that there is a need to club both hazardous and non-hazardous work as child labour, and a serious need to amend the law on child labour to include every kind of child labour as hazardous to children ${ }^{14}$. On 28 August 2012, the cabinet approved a new law - Child and Adolescent Labour (Prohibition) Act, proposing a complete ban on employment of children under the age of 14 in all areas of work. While supporting the move, activists also warned that without sufficient political backing, effective implementation, adequate budgets and robust enforcement, the amended law could remain on the statute book without any impact for the estimated 12.6 million under-14s working in the country ${ }^{15}$.

\subsection{Law and policy in action}

The judiciary has been conscious of the strong link between child labour and education of children. An important judicial intervention in the action against child labour in India was the M.C. Mehta case (1996) in which the Supreme Court, directed the Union and state governments to identify all children working in hazardous processes and occupations, to withdraw them from work, and to provide them with quality education ${ }^{16}$. The Court also directed that a Child Labour Rehabilitation-cumWelfare Fund be set up using contributions from employers who contravene the Child Labour Act. In addition, in 1993, the Supreme Court in Unnikrishnan v. State of Andhra Pradesh ${ }^{17}$ stated that each child has the right to free education until he or she completes the age of 14 years. Article 21-A was subsequently inserted into the Constitution to reflect this standard. In Rajangam, Secretary, District Beedi Workers' Union vs. State of Tamil Nadu, the Supreme Court passed strictures to prohibit child labour since the beedi industry was hazardous to the life and health of children ${ }^{18}$.

In 2005, three non-profit organisations working on child rights - the M.V. Foundation, HAQ: Centre for Child Rights and Social Jurist- filed a public interest litigation in the Supreme Court of India challenging the validity of the Child Labour Act in the wake of the constitutional guarantee to right to education for children in the 6-14 
age-group.They argue that child labour up to the age of compulsory education is unconstitutional and is a negation of rights under Article 21-A which provides for compulsory education up to the age of 14 . The petition questions as to how children can be at work and at school at the same time, and that this means that any attempt to give them access to education will be second-rate, parallel non-formal education. The petition contends that the existing legislations on child labour which were not completely prohibiting it in all occupations and processes, were resulting in negation of all the fundamental and human rights guaranteed to the children under Article 14, 21-A, 23, 24, 39 (e) 39 (f), 41, 45 and 51-A (h), 61-A (j),51-A (k) of the Constitution read with U.N. Convention on the Rights of the Child and ILO Minimum Age Convention, 1973. This case is pending before the Supreme Court. Notably however, under this case the Court has asked the Government to file a status report on the implementation of Sarva Shiksha Abhiyan - a government programme providing free and compulsory education to all children.

As on many other issues, there exists a gap between the legal standards and reality. In many Indian industries, girls are unrecognised labourers because they are seen as helpers and not workers. Therefore, girls are therefore not protected by the law.The National Child Labour Project (NCLP) scheme, which provides for Rs. 100 as stipend per month to each child labourer withdrawn from work, has come under criticism from persons, including the chairperson of NCPCR, who observed: "'The Rs 100 stipend is on official papers only. I wonder how many kids receive this monthly stipend". ${ }^{19}$ Moreover, despite the fact that India has formulated laws and policies to protect adolescent girls in labour, the issue is still caught between legal and policy commitments to children on the one hand, and the fallout of the process of globalisation on the other. The statistics below (Table 1) indicate the level of enforcement of the law on child labour, and highlight the fact that out of the number of violations detected, only a small number of prosecutions are launched, out of which an even smaller number convicted.

Despite the existence of the law, reports from the M V Foundation in Andhra Pradesh reveal that nearly 400,000 children, mostly girls between 7 and 14 years of age, toil for 14-16 hours a day in cotton seed production across the country and that ninety percent of them are employed in Andhra Pradesh alone ${ }^{20}$.

\subsection{Bonded Labour}

Bonded labour is a system of forced, or partially forced, labour under which the debtor enters into an oral / written agreement with the creditor. According to this 
agreement, in consideration of an 'advance' obtained by the debtor or by any of his lineal ascendants and in consideration of the interest on such an advance, the debtor agrees to render, by himself or through any member of his family, labour for the creditor for a specified / unspecified period of time either without wages or for nominal wages.

Table 1: Enforcement of Child Labour (Prohibition and Regulation) Act, 1986

(Based on reports received from the State Governments \& CLC)

\begin{tabular}{|l|c|l|c|c|c|}
\hline Year & $\begin{array}{l}\text { No. of } \\
\text { inspections } \\
\text { carried out }\end{array}$ & $\begin{array}{l}\text { No. of } \\
\text { violations } \\
\text { detected }\end{array}$ & $\begin{array}{l}\text { Prosecutions } \\
\text { launched }\end{array}$ & Convictions & Acquittals \\
\hline $\mathbf{1 9 9 7 - 9 8}$ & 288150 & 25909 & 19496 & 6073 & 157 \\
\hline $\mathbf{1 9 9 8 - 9 9}$ & 222856 & 11263 & 6469 & 4125 & 725 \\
\hline $\mathbf{1 9 9 9 - 2 0 0 0}$ & 242269 & 7598 & 3972 & 1333 & 356 \\
\hline $\mathbf{2 0 0 0 - 0 1}$ & 189842 & 10537 & 2398 & 1036 & 343 \\
\hline $\mathbf{2 0 0 1 - 0 2}$ & 449042 & 16604 & 9201 & 1799 & 606 \\
\hline $\mathbf{2 0 0 2 - 0 3}$ & 372504 & 28850 & 5660 & 1717 & 2229 \\
\hline $\mathbf{2 0 0 3 - 0 4}$ & 346212 & 26411 & 9221 & 4013 & 642 \\
\hline $\mathbf{2 0 0 4 - 0 5}$ & 242223 & 16632 & 2609 & 1385 & 447 \\
\hline Total & $\mathbf{2 3 5 3 0 9 8}$ & $\mathbf{1 4 3 8 0 4}$ & $\mathbf{5 9 0 2 6}$ & $\mathbf{2 1 4 8 1}$ & $\mathbf{5 5 0 5}$ \\
\hline
\end{tabular}

Source: Ministry of Labour, Government of India, http://labour.nic.in/cwl/ChildLabour.htm

Through this agreement, the debtor is deprived of freedom of employment, freedom to sell at market value any product of the debtor's or his / her family members' labour and the right to move freely throughout India. The system is known by different names in different parts of the country, including begar, sagri / hali and jeetham. The causes of bonded labour include poverty, unemployment/underemployment, inequitable distribution of land and assets, low wages, distress migration and social customs. The system draws heavily upon traditional feudal social relations, the caste system, social hierarchy and discriminatory practices that are prevalent in society. Such systems thrive in agriculture, brick kilns, stone quarries, crushers and mines, power looms and cotton handlooms, as well as in construction and other industries.

People considered 'untouchables', adivasis, women and children are among the main victims of the bonded labour system, as they have a lower social ascription and fewer perceived rights. In addition to other forms of exploitation and abuse, female 
bonded labourers are vulnerable to wage discrimination, physical abuse and sexual exploitation by the creditor and his family members / relatives. The malnutritionrelated death of Katraju Lakshmi - a Chenchu tribal woman from Andhra Pradesh who worked as a bonded labourer on construction sites in Meghalaya, is a case in point $^{21}$. Hard physical labour at construction sites, combined with denial and discrimination in wages and lack of food, caused Lakshmi's death in 2006.

\subsection{Legal and policy response}

The Constitution, in the chapter on fundamental rights, prohibits traffic in human beings and forced labour ${ }^{22}$. The Bonded Labour System (Abolition) Act 1976 was enacted to abolish the bonded labour system, as it is exploitative, violative of human dignity and is contrary to basic human values ${ }^{23}$. The law unilaterally frees all bonded labourers from debt bondage, with simultaneous liquidation of their debts. The law lays down monitoring, enforcement and implementation modalities, which mainly rest on state governments. A series of progressive judgments of the Supreme Court has attempted to monitor the implementation of the law. Pursuant to a 1997 directive of the Supreme Court, the National Human Rights Commission (NHRC) has been vested with the responsibility of monitoring the implementation of the law and making reports to the Court from time to time ${ }^{24}$.

\subsection{Law and policy in action}

In Bandhua Mukti Morcha vs. Union of India, the Supreme Court dealt with the release of bonded labourers from stone quarries in Haryana ${ }^{25}$. Despite a formal abolition of the system by law and some positive judgments, it continues to exist in practice. An example of the manner in which the bonded labour system works, in particular relevance to adolescent girls, is the Sumangali scheme in Tamil Nadu.

In February 2006, the State Textile Workers Federation made a representation through the Centre of Indian Trade Unions (CITU), to the Government of Tamilnadu, alleging that the Textile Mills in Tamilnadu were indulging in an exploitative practice of engaging adolescent girls under a scheme known as Thirumagal Thirumana Thittam (Marriage Scheme for Adolescent Girls) and that the same amounted in fact, to forced labour. In January 2007, a notification was issued by the government of Tamil Nadu, including the employment in textile and spinning mills within Part I of the Schedule to the Minimum Wages Act. Thereafter the Chief Inspector of Factories submitted a report to the state government, confirming that girls above the age of 15 were employed in spinning mills for 3 year apprenticeship, and that after completion, the girls were paid Rs. 30,000 - Rs. 50,000 as 
a lump sum amount to meet their marriage expenses. The report also contained the total number of mills and girls who were employed - 7810 in Erode, 21599 in Coimbatore and 9052 in Dindugul-a total of 38,461 girls employed in 406 mills. The report further said that there had been some incidents of sexual harassment. The report recommended that since it might be impossible to abolish the system all of a sudden, it would be better to appoint monitoring committees at the district level. Accordingly, the state government appointed district monitoring committees in the three districts mentioned above ${ }^{26}$. At about the same time, a civil society organization - Society for Community Organization (SOCO) Trust complained to the National Human Rights Commission (NHRC), alleging that thousands of girls in the age group of 15 to 20 were employed as bonded labourers by certain Textile Mills, under some dubious schemes known as Sumangali Marriage Thittam and Thirumagal Thirumana Thittam. Based on directions from the NHRC, the state government began identifying mills where young girls were employed as apprentices, examining their working conditions and advising the measures to be taken for prevention of exploitation of young girls in the guise of apprentices.

The Sumangali scheme, which is a form of forced labour in India, is said to have started in 1989. The word "Sumangali" in Tamil means an unmarried girl becoming a respectable woman by entering into marriage. Thus, the scheme is also known as "marriage assistance system". Under this scheme, girls' parents, usually poor and from the lower castes, are persuaded by brokers to sign up their daughter(s). The scheme promises a bulk of money after completion of a three-year contract working in the factory. The scheme, prevalent largely in the spinning mills of Coimbatore, Tamil Nadu, supposedly meets the need of poor families and provides stable workforce to factories. The scheme is clearly exploitative in nature, as it provided the girls an approximate daily wage of Rs. 50 a day, nearly three times lesser than the legal minimum wage in Coimbatore in 2008. Once the contract is signed, young girls are under the control of the factory or the broker. It is often reported that the girls lived in captivity for a long period. Some factories are reported to fire the girls or make them resign shortly before they finish the three- year contract so as to avoid paying the marriage assistance fund, ranging from Rs. 30,000 to Rs.50,000 ${ }^{27}$.

In the words of a civil society organisation, under this Sumangali Plan, these girls are housed within the textile factories, under conditions seemingly like a mini jail. Agents select girls to work at these factories for a 6 month trial. After this period the best workers are employed as cheap child labour and the rest of girls are returned to the village without any pay. The selected girls are contracted for 18 hours a day to work for 3 years, to supplement their families' income and save for their marriage dowry, whilst 
being subjected to the sexual harassment and exploitation of labour. Their wage is their food and board, they are promised Rs.36000/- lump sum at the end of the 3 years. But many girls are reportedly dismissed just prior to the 3 year period ending up with no payment at all or just given invalid bank cheques by some of the companies. Working conditions for girls are even worse than those of their male counterparts, and many are treated little better than slaves. Many are subjected to sexual harassment which can leave permanent physical and mental scars.

In November 2008, the state government, through a government order, fixed minimum wages of Rs. 110/- per day apart from dearness allowance as detailed in the order, to apprentices engaged in employment in textile mills ${ }^{28}$. This order was challenged through many writ petitions in the Madras High Court before a single judge, where they were all dismissed, and the government order upheld ${ }^{29}$. On appeal before a division bench of the Madras High Court, the court affirmed the single judge's $\operatorname{order}^{30}$.In 2009, a public hearing on the issue was organised by the Tamil Nadu State Commission for Women, which recommended cash compensation. In 2010, it was reported that a 17 years old girl escaped from a private mill in Coimbatore, where she had been trapped for five years ${ }^{31}$. In July 2012, civil society renewed its demand for monitoring of companies implementing the Sumangali scheme ${ }^{32}$. Despite the various interventions of the state government, NHRC, the judiciary and civil society organisations, exploitation in the form of bonded and forced labour of adolescent girls reportedly continues in the Tamil Nadu textile and garment industry at present ${ }^{33}$.

According to government estimates more than thirty seven thousand adolescent girls are trapped in this system across Tamil $\mathrm{Nadu}^{34}$. The Sumangali scheme is a complex issue involving adolescent girls, embedded in and deriving strength from a combination of factors: the Indian context of patriarchy, gender discrimination, low social value for girls, the importance attributed to marriage of girls, the practice of dowry and the perception of girls as a financial burden. The case study from Tamil Nadu discussed above is a mere example of the phenomenon of employing girls in bonded / forced / exploitative labour. Another study reveals the practice in Andhra Pradesh, where local seed farmers, who cultivate hybrid cottonseed for national and multinational seed companies, secure the labour of young girls by offering loans to their parents in advance of cultivation, compelling the girls to work at terms set by the employer for the entire season, and, in practice, for several years ${ }^{35}$. Experts say that despite the legal provisions, identification and release of bonded labourers is always challenging, as only a small number are identified, that too with the persistent efforts of non-profit organizations, and that the rehabilitation of migrant labourers is often neglected (Srivastava, 2005). Moreover, very few employers got prosecuted and even 
fewer got convicted. According to the Ministry of Labour's figures, between 2000 and 2002 in all of India, there were only around 1800 bonded labourers being identified and released; and another around 17300 bonded labourers rehabilitated. However, there was no data showing how many child labourers are among those being freed, and how many of them were adolescent girls (Human Rights Watch, 2003, p. 50).

\subsection{Sexual Harassment at Workplace}

Sexual harassment at the workplace is an important issue related to the safety and dignity of girls in workplaces. Sexual harassment is an expression of male power over women and girls that sustain patriarchal relations, and is often an extension of violence against women and girls in everyday life, targeting and exploiting their vulnerability at the workplace. It is a manifestation of power relations women are much more likely to be victims of sexual harassment precisely because they lack power, are in a more vulnerable and insecure position, lack selfconfidence, or have been socially conditioned to suffer in silence (ILO, 2000). The cases of sexual harassment of women and girls at the workplace are increasing alarmingly because of several factors, such as the poor status of women, patriarchy and gender discrimination, increasing number of working women which results in a 'threat' perception among certain men, poor knowledge of human relations, and inadequate provisions of law to deal with the problem effectively. Sexual harassment at the workplace is not only an issue related to empowerment of women and girls and an issue of occupational safety and health, but is also an issue pertaining to human rights, as the right to life ought to include the right to work in an environment that is conducive to human dignity.

Sexual harassment of women at workplace is also a violation of the right to life and personal liberty as mentioned in Article 21 of the Indian Constitution states that no person shall be deprived of his life or personal liberty. Right to livelihood is an integral facet of the right to life, and consequently sexual harassment at the workplace is the violation of the right to livelihood, as it deprives the woman and girl of a safe working environment.

\subsection{The definition}

In common parlance, there is only a thin line distinguishing between casual flirting and sexual harassment. The Supreme Court laid down the definition of sexual harassment as "any unwelcome sexually determined behaviour such as physical contact, a demand or request for sexual favours, sexually-coloured remarks, showing pornography and any other unwelcome physical, verbal or non-verbal conduct 
of a sexual nature." It includes leering, dirty jokes, sexual remarks about a person's body, sexual advances either verbal or through gestures or through the use of sexually suggestive or pornographic material, whistling, sexually slanting and obscene remarks or jokes, comments about physical appearance, demands for sexual favours, threats, avoidable physical contact, touching, patting, pinching, physical assaults and molestation of and towards women workers by their male colleagues or anyone who for the time being is in a position to sexually harass the women under their fold.

In Apparel Export Promotion Council v. A.K. Chopra (1999, 1 SCC 759), the Supreme Court further explained the definition of 'sexual harassment' in Vishaka judgment as follows:

An analysis of the above definition, shows that sexual harassment is a form of sex discrimination projected through unwelcome sexual advances, request for sexual favours and other verbal or physical conduct with sexual overtones, whether directly or by implication, particularly when submission to or rejection of such a conduct by the female employee was capable of being used for effecting the employment of the female employee and unreasonably interfering with her work performance and had the effect of creating an intimidating or hostile working environment for her.(para 27)

\subsection{Landmark judgement of the Supreme Court}

The Supreme Court pronounced a landmark judgment on sexual harassment of working women in 1997 in Vishaka and Others vs. State of Rajasthan ${ }^{36}$. In this judgment, the court stated that sexual harassment of working women (including girls) as a form of discrimination against women and violation of the constitutional right to equality.The backdrop to this judgment was the gang rape of a sathin, Bhanwari Devi in 1992, who was employed by the Rajasthan government in its women's development programme to prevent child marriages. A group of women's organizations came forward to file a public interest litigation (PIL) in the Supreme Court, asking for directions and guidelines to ensure the constitutional rights of women to work in a violence-free work environment. The landmark judgment was significant in recognizing sexual harassment at the work place as a violation of the constitutional rights of women and outlining guidelines for the prevention, deterrence and redress of sexual harassment.

The judgment also provided guidelines for employers to redress and prevent sexual harassment at workplace, and to provide a discrimination-free working environment for women employees. The judgment said that it was the duty of the employer or other responsible persons in work places to provide women with a 
safe working atmosphere, to prevent sexual harassment as well as provide mechanisms for resolution of complaints through the establishment of complaints committees.

The Court further directed every workplace to constitute a committee for receiving and inquiring into complaints of sexual harassment. As per the directives of the court, every such committee should consist of members of whom at least $50 \%$ are women, a chairperson who is a woman and an external member from a social work / non-profit organisation. It also outlined preventive steps that the employer ought to take, including discussing the issue affirmatively in workers' meetings and employer-employee meetings, prominent display of guidelines to create awareness of the right of women employees, and prominent display of members of the complaints committee and their contact details. The employers are also responsible for formulating an anti-sexual harassment policy, and for constituting a complaints committee to investigate, mediate, counsel and resolve cases of sexual harassment. A separate law on the issue is being drafted. In the absence of any written law, the judgment is legally binding and final on the issue.

\subsection{The law and policy in action}

Though the Supreme Court judgment has shifted the onus on the employers in public and private sectors to ensure women employees' safety at the workplace, formulating an anti-sexual harassment policy and setting up a complaints committee are not priorities for companies. Hence the law is violated rampantly. The Supreme Court directives mandate all offices to constitute a committee to prevent and redress such cases. However, most workplaces do not constitute a committee till an incident of sexual harassment occurs. Unless a criminal case has been filed, the consequences of the enquiry are usually in the form of a reprimand, demotion, suspension, dismissal or being asked to tender an apology.

An important contributory factor to non-implementation of the law is the lack of awareness among women and girls. In a research by Sakshi - a women's organization - it was found that $58 \%$ of the women were not aware of the Supreme Court guidelines ${ }^{37}$. Despite the law, many cases go unreported as women are reluctant to lodge complaints of sexual harassment against their colleagues, for fear of being labeled a "loose woman", the accompanying social stigma and protracted litigation in courts of law.

The National Commission for Women (NCW) commissioned a project on "Sexual harassment of women at work place" in various cities. The study reveals that nearly $60 \%$ of the working women are not aware of the guidelines given by the 
Supreme Court of India in Vishakha case. It was further found that even many of the employers are not aware of the Supreme Court guidelines and have not constituted a committee in pursuance of the guidelines. Thereafter, the NCW had prepared the code of conduct at work place in pursuance of the Supreme Court guidelines and circulated the same to all the ministries, educational institutions, public and private sector undertakings and various NGOs for information and implementation.

Despite the Vishaka guidelines, there have been many instances of sexual harassment in various private workplaces such as educational institutions, Bar Associations, Medical Councils and other professional and technical associations, where compliance to the Guidelines do not exist. In this context, in 2004, through a public interest litigation in Medha Kotwal versus Union of India and others ${ }^{38}$, an implementation of the guidelines issued by the Supreme Court in Vishaka's case was sought.

An application under the Right to Information Act, filed with the Labour Commissioner in Maharashtra in 2007 revealed that no concrete measures had been taken by it despite the Supreme Court's order in the Medha Kotwal case ${ }^{39}$. Another application filed under the Right to Information (RTI) with the Maharashtra State Women Commission revealed that 60 complaints of sexual harassment at the workplace were filed in four months between January 1, 2008 and April 30, 2008.

In 2010, The Protection against Sexual Harassment of Women Bill was drafted. The bill makes it mandatory for all workplaces, including homes, universities, hospitals, government and non-government offices, factories, other formal and informal work places to constitute an internal committee for redress of complaints. On 3 September 2012, the Bill - The Sexual Harassment of Women at Workplace (Prevention, Prohibition and Redressal) Bill 2010 - was passed by LokSabha. One of the major provisions of the Bill, which is of serious concern to women's rights activists and advocates, is that which penalizes the complainant if the internal committee or the local committee concludes that the allegation of sexual harassment was maliciously made, or was false ${ }^{40}$. This provision will have a chilling effect on women who are subjected to sexual harassment at the workplace, and deter them from complaining ${ }^{41}$.

\subsection{Conclusion}

Lack of implementation of laws, lack of awareness of rights enshrined in the laws coupled with a lack of access to justice for adolescent girls, brings to the fore the importance of pro-active policies for adolescent girls at work as a complementing strategy. "Kishori Shakti Yojana" - an adolescent girls' scheme sponsored by the 
central and state government of Haryana - is a case in point where adolescent girls are trained and equipped to improve their home-based and vocational skills. The scheme was commenced with the objective of improving the nutritional and health status of adolescent girls between 11-18 years of age, to train and equip them to improve home-based and vocational skills, to promote awareness of health hygiene, nutrition, home management, child care, and take all measures as to facilitate their marriage after attaining the age of 18 years and even later. This scheme is being implemented through anganwadi centres. Such schemes need to be taken up at a larger, nationwide scale to make a meaningful and long-term impact on economic empowerment of adolescent girls.

In conclusion, instead of viewing adolescent girls only through the lens of their natal families, they should be seen as individuals in their own right, who require laws and policies for protecting and promoting their rights. Micro-credit facilities and facilities for on-site banking facilities for girls and young women at their place of work are some such strategies. The policies should be geared towards supporting adolescent girls for building skills such as life skills and vocational skills, and for having savings independent of their families, in order that they can become economically independent. Laws related to eradication of child labour, bonded labour and protecting girls at the workplace ought to be implemented in a rigorous manner.

\section{Endnotes}

1. International Labour Organization, Global Employment Trends for Youth, August 2010, p. 2.

2. Ibid, pp. 3-6.

3. ILO defines workers in vulnerable employment as the sum of own-account workers and contributing family workers. They are less likely to have formal work arrangements, and are therefore more likely to lack decent working conditions, adequate social security and 'voice' through effective representation by trade unions and similar organizations. Vulnerable employment is often characterized by inadequate earnings, low productivity and difficult conditions of work that undermine workers' fundamental rights. For more details, see http://www.ilo.org/global/about-the-ilo/newsroom/features/WCMS_120470/lang-en/index.htm (accesses October 10, 2012).

4. European Council Directive 94/33/EC of 22 June 1994 on the protection of young people at work. Summary of the directive is available at http://www.europa.eu.int, (accessed 15 September 2012). 
5. Council Directive 92/85/EEC of 19 October 1992 (Tenth individual Directive within the meaning of Article 16(1) of Directive 89/391/EEC.). Summary available at http://www.europa.eu.int_accessed 15 September 2012).

6. The Government of India, through the $86^{\text {th }}$ amendment Act of 2002, inserted Art. 21 A to the Indian Constitution, which states that the state "shall provide free and compulsory education to all children of the age of 6 to 14 years as the state may, by law determine."

7. See ss.19 22(2), 27, 42(1)(b), 48, 66, 79(1) and 114.

8. For an elaboration of labour laws in general and those pertaining to women, please see Bhasin, Lalit (2007) and Sharma, Parul (2007).

9. $\operatorname{UNICEF}(2001)$, p. 10

10. Bajpai, Asha (2003), p. 156.

11. T he 11th Five Year Plan, Volume II, available at http://planningcommission.nic.in, accessed 8 September 2012.

12. Notification in the Official Gazette, dated 10 October 2006.

13. Gazette Notification by the Ministry of Labour and Employment (Child Labour Section), Government of India, dated 25 September 2008.

14. 'NCPCR Head Advocates Amendment in Child Labour Act', http://zeenews.india.com/news/nation/ncpcr-head- advocates-amendment-in-child-labouract_781223.html, accessed 8 September 2012

15. 'A Move that could Help Reduce Child Labour', The Wall Street Journal, 29 August 2012.

16. M C Mehta vs State of Tamil Nadu(1996) 6 SCC 756: AIR 1997 SC. 699.

17. AIR 1993 SC 217: 1993 SCR (1) 594: 1993 SCC (1) 645.

18. AIR 1993 SC 401.

19. 'NCPCR Head Advocates Amendment in Child Labour Act', http://zeenews.india.com/news/nation/ncpcr-head-advocates-amendment-in-child-labouract_781223.html, accessed 1 September 2012 
42 | PRAGATI: Journal of Indian Economy, Volume 2, Issue 2

20. HAQ: Centre for Child Rights (2005), p. 169; see also 'Girls Fettered: Bonded Labour on AP Farms', Deccan Herald, 17 May 2003.

21. For more details, see $h t t p: / / w w w . f i a n . o r g / c a s e s / l e t t e r-c a m p a i g n s / i n d i a-f a i l u r e-o f-s t a t e-$ social-programmes- leads-to-bonded-labour-of-600-chenchu-tribals-and-the-death-of-achenchu-woman. accessed 4 December 2009.

22. Article 23 of the Indian Constitution.

23. The words of the Supreme Court in the Asiad Workers case - People's Union for Democratic Rights vs. Union of India AIR 1982 SC 1473.

24. Order dated 11 November 1997 in PUCL vs. State of Tamil Nadu and others.

25. AIR 1984 SC 802.

26. G.O.Ms.No.62, Labour and Employment department, dated 30-3-2007.

27. Sindhu Menon, Adolescent Dreams Shattered in the Lure of Marriage: Sumangali System: A New Form of Bondage in Tamil Nadu, available at http://labourfile.org/ArticleMore.aspx?Id=826, accessed 1 June 2012.

28. G.O. (2D) No.61, Labour and Employment (J1) Department of State of Tamil Nadu, dated 7.11.2008.

29. Tamil Nadu Spinning Mills vs The State of Tamil Nadu, judgment dated 30 April 2009.

30. The Southern India Mills vs The State of Tamil Nadu, judgment dated 11 December 2009.

31. P.V. Srividya, 'She Escaped from Rigours of Bonded Labour', The Hindu, 17 September 2010 , available at http://hindu.com/2010/09/17/stories/2010091753340500.htm, accessed 1 June 2012.

32. Monitoring of Companies under the Sumangali Scheme Demanded', The Hindu, 18 July 2012.

33. B. Aravind Kumar, Exploitation Continues at Garment Hub, The Hindu, 8 March 2012.

34. 'Bonded Labour at Mills for Unmarried Girls', http://www.ndtv.com/article/india/bondedlabour-at-mills-for- unmarried-girls-9657, accessed 1 July 2012. 
35. 'Girls Fettered: Bonded Labour on AP Farms', Deccan Herald, 17 May 2003; see also data.undp.org.in/childrenandpoverty/ref/Davuluri.htm, accessed 1 July 2012.

36. Vishaka\& others vs. State of Rajasthan AIR 1997 SC 3011: (1977) 6 SCC 341.

37. Sucheta Dalal, 'Bias in the Boardroom', The Sunday Express, May 182003.

38. WP (Crl.) Nos.173-177/1999 decided on 26.4.2004.

39. Yedhula,Prakash (2009).

40. Section 14 of the bill calls for action against the complainant in case the "internal committee or the local committee, as the case may be, arrives at a conclusion that the allegation against the respondent is malicious or the aggrieved woman or any other person making the complaint has made the complaint knowing it to be false."

41. For a comprehensive critique of the Bill, see Jaising, Indira. 'Complainant in the Dock', The Indian Express, 17 September 2012; Sarpotdar, Anagha. 'Breaking her Silence', The Indian Express, 8 September 2012.

\section{References}

Bajpai, Asha (2003), Child Rights in India: Law, Policy, and Practice, New Delhi: Oxford University Press.

Bhasin, Lalit (2007), Labour and Employment Laws of India, 24 August 2007, available at http://www.mondaq.com/article.asp?articleid=50440, accessed 27 January 2009.

HAQ: Centre for Child Rights. (2005). Status of Children in India Inc. New Delhi: HAQ Centre for Child Rights.

Human Rights Watch. (2003). Small Change: Bonded Child Labour in India's Silk Industry. 15(2): January.

India Committee of the Netherlands (ICN) and the Centre for Research on Multinational Corporations (SOMO). (2011). Captured by Cotton: A Study of Dalit Girls Working Under Slave-like Conditions in India's Garment Industry. 
44 | PRAGATI: Journal of Indian Economy, Volume 2, Issue 2

International Labour Organization. (2000). Sexual Harassment: Gender! A Partnership of Equals. 58.

International Labour Organization. (2010) Global Employment Trends for Youth.

Jaising, Indira. (2012). Complainant in the Dock. The Indian Express, 17 September.

NFHS-3 International Institute for Population Sciences (IIPS) and Macro International (2007). National Family Health Survey (NFHS-3), 2005-6, India: Volume 1, Mumbai: IIPS.

Planning Commission of India. (2012). The 11th Five Year Plan, Volume II, New Delhi: Government of India.

Sarpotdar, Anagha. (2012). Breaking her Silence. The Indian Express, 8 September.

Sharma, Parul (2007). Split Legal Regime in India's Labour Laws, Journal for Sustainable Development, February-March.

Solidaridad-South and South East Asia (2012), Understanding the Characteristics of the Sumangali Scheme in Tamil Nadu Textile and Garment Industry and Supply Chain Linkages, Washington: Fair Labour Association.

Srivastava, Ravi S. (2005), Bonded Labour in India: Its Incidence and Pattern, Working Paper, Declaration/WP/43/2005, Geneva: International Labour Office.

UNICEF. (2001). Beyond Child Labour, Affirming Rights, New York: UNICEF Division of Communication.

Yedhula, Prakash. (2009). Sexual Harassment at the Workplace: Implement the Guidelines. Lawyers Club India, 21 Jan, available at http://www.lawyersclubindia.com/articles/Sexual-Harassment-at-the-WorkplaceImplement- the-Guidelines-613.asp\#.UAlSvFKGEYc, accessed 22 July 2012. 